\title{
Changes in temperature of newborn babies bathed immediately after birth
}

\author{
Eka Gunawijaya, Abdul Hamid S
}

\begin{abstract}
Abstrak
Memandikan bayi segera setelah lahir masih umum dikerjakan di daerah tropis, meskipun sudah ada anjuran untuk memandikan bayi saat 2 sampai 6 jam setelah lahir. Sampai saat ini belum pernah diteliti kejadian hipotermia pada bayi yang segera dimandikan setelah lahir di Indonesia. Penelitian ini bertujuan untuk mengetahui pengaruh memandikan bayi segera setelah lahir terhadap perubahan suhu tubuhnya dan kemungkinan terjadinya hipotermia. Subyek penelitian ialah 125 bayi yang lahir pada bulan Maret 1999, terbagi dalam dua kelompok yaitu 59 bayi segera dimandikan dan 66 bayi tidak segera dimandikan setelah lahir. Tidak terdapat diantara kedua kelompok dalam hal rerata berat badan lahir, masa gestasi, suhu ruangan, jenis kelamin, cara persalinan, dan risiko infeksi. Rerata suhu tubuh di antara kedua kelompok pada menit ke-0 dan menit ke-30 tidak menunjukkan perbedaan bermakna, sementara pada menit ke-15 tampak suhu tubuh kelompok yang segera dimandikan lebih rendah secara bermakna daripada kelompok yang tidak segera dimandikan setelah lahir [36,84 (SB 0,25) ${ }^{\circ} \mathrm{C}$ berbanding 37,02 (SB 0,27) ${ }^{\circ} \mathrm{C}$, p=0,0001]. Pada menit ke-15 setelah lahir ditemukan empat $(6,8 \%)$ bayi mengalami hipotermia (suhu rektal $<36,5^{\circ} \mathrm{C}$ ) di antara kelompok yang segera dimandikan dan satu hipotermia $(1,5 \%)$ di antara kelompok yang tidak segera dimandikan $(p=0,134)$. Kesimpulan, memandikan bayi cukup bulan yang sehat segera setelah lahir akan mengakibatkan penurunan suhu tubuh bayi, tetapi secara statistik belum mengakibatkan hipotermia yang bermakna. (Med J Indones 2003; 12: 73-80)
\end{abstract}

\begin{abstract}
In the tropics, bathing full-term newborn babies are routinely done immediately after birth, although it is usually not recommended until $2-6$ hours of age. Yet, there is no study in Indonesia about hypothermia in newborns bathed immediately after birth. The aim of this study is to determine the influence of bathing the newborn immediately after birth to the body temperature and hypothermia. One hundred and twenty five healthy full-term newborn babies delivered on March 1999 were included and separated into two groups,59 newborns were bathed immediately after birth and 66 newborns were bathed later. There was no statistical difference between both groups in the mean of birth weight, gestational age, room temperatures, gender, delivery method, and risk of infection. Mean body temperature between both groups were not statistically different on the 0 and the $30^{\text {th }}$ minute after birth. On the other hand, on the $15^{\text {th }}$ minute after birth, the mean body temperature of the immediately bathed group was statistically lower than not immediately bathed group [36.84 (SD 0.25) ${ }^{O} \mathrm{C} v \mathrm{~s} 37.02$ (SD 0.27) $\left.{ }^{O} \mathrm{C}, \mathrm{p}=0.0001\right]$. On the $15^{\text {th }}$ minute after birth, there were four (6.8\%) hypothermic babies (rectal temperature $<36.5^{\circ} \mathrm{C}$ ) in the immediately bathed group and one $(1.5 \%)$ hypothermic baby in the not immediately bathed group ( $p=0.134)$. Conclusion, bathing healthy full-term newborn babies immediately after birth will decrease the body temperature, but hypothermia occurred only in very small numbers which are not statistically significant. (Med J Indones 2003; 12: 73-80)
\end{abstract}

Keywords: hypothermia, neworn baby, bathed immediately after birth

Controlling the temperature of the newborn baby is very essential to avoid the occurrence of hypothermia which theatens the life of the baby. ${ }^{1}$ Hypothermia is the decrease of body temperature to the level of < $36.5^{\circ} \mathrm{C}$ rectally. ${ }^{2,3}$ Hypothermia can occur anywhere, even in a region with a tropical climate. The causes of hypothermia in the newborn baby are the mishandling of the baby during delivery or after, the condition in the delivery room, asphyxia, premature or low birth

Department of Child Health, Denpasar Public Hospital, Bali, Indonesia weight, and use of anesthetic drug to the mother. ${ }^{3-4}$ Mishandling causes the newborn baby to lose temperature in 4 ways, namely through evaporation, conduction, radiation, and convection. ${ }^{1-6}$ The clinical symptoms of hypothermia in the baby include the following: the legs are cold before the coldness extends to the body, the activity decrease and becomes lethargic, and the cry is weak. If hypothermia persists, it result in: change in the respiration (getting slower, short, and irregular), bradycardia, hypoglycemia, metabolic acidosis, and even death of the baby. ${ }^{1,2,5}$ The concept of a "warm chain" includes: training the personels, preparing the 
place of delivery (clean, warm, and draught-free room), immediately drying the newborn baby, wrapping the baby in a blanket and giving it to the mother quickly after birth, putting the baby to the mother's breast, putting a warm cap on the baby's head, covering the baby and mother together, ensuring warm and safe transport if necessary. ${ }^{1,2}$

In reality, bathing the baby immediately after birth is still generally practiced in the tropical areas including Indonesia, despite WHO's suggestion not to bath the baby immediately after birth. There is a concern that hypothermia will occur due to instability in the thermoregulation of the baby's body immediately after birth. It is recommended that the baby be bathed instead at 2 to 6 hours after birth. ${ }^{1,2}$ The provisionally established regulation in Denpasar Public Hospital which requires that newborn babies be not immediately bathed after birth started to be in force on March 15, 1999. There is no previous study in Indonesia on the occurrence of hypothermia caused by the bathing of the baby immediately after birth. This study is aimed at learning the effect of bathing the newborn baby immediately after birth upon the change of its body temperature, and the potential occurrence of hypothermia.

\section{METHODS}

The study in prospectively conducted by doing experimental test over two groups of newborn babies, divided into a group immediately bathed after birth and a group not immediately bathed after birth. The samples used are 139 term babies born in Denpasar Public Hospital, in March 1999, 67 of which were immediately bathed after birth and 72 not immediately bathed after birth. The immediately bathed group was examined before the provisionally established regulation (on March 15, 1999), and the other group was examined after. The samples were excluded whenever there were such conditions as the following: too low room temperature, birth before mature age of pregnancy or with low birth weight, birth in asphyxia condition, and born with congenital abnormality. The parent informed consent had been performed before the study.

Conventionally, bathing the newborn babies was done immediately after birth, namely 10 minutes after birth. This was found in this study too, namely the immediately bathed group. The bathing of the baby was done for 1 to 2 minutes using the water obtained from the tap water with its temperature adjusted to $39^{\circ} \mathrm{C}$ using water warming machine (Atom, JapanIndonesian Incoorporation). The tap water temperature will interfere with bath tub and air temperature, until it become decreased to $37-38^{\circ} \mathrm{C}$. After being bathed, the baby's body was dried with towel, the head and body was wrapped, and was laid down on the bed with plastic underlayer at $50 \mathrm{~cm}$ distance below radiant warmer (Atom, Japan-Indonesian Incoorporation) for 30 minutes. There was no increased air flow in the room of the baby, for the purpose of preventing increased loss of heat from the baby.

The group of babies not immediately bathed in this study were bathed after 2 to 6 hours after birth. Except for the time after birth the baby was bathed, both groups were treated in an identical manner. The body weight was measured by infant body weight scales device (Atom, Japan-Indonesian Incoorporation) at 1 hour after bath.

The baby's temperature was measured by mercury thermometer (Phillip Harris Limited, England) inserted into the rectum as deep as $2 \mathrm{~cm}$ and for at least 1 minute. ${ }^{8,9}$ The measurement of the room temperature of the location where the baby was placed was by using mercury thermometer (Thomas Phila, USA), laid down close to the baby, namely on the bed side of the baby which adjusted to the level below radiant warmer. The measurement of the baby's and the room's temperatures was done at three simultaneous moments, namely on the $0,15^{\text {th }}$, and $30^{\text {th }}$ minutes after birth.

The baby was considered normothermic if its rectal temperature was between $36.5-37.5^{\circ} \mathrm{C}$, and hypothermia if the rectal temperature was $<36.5^{\circ} \mathrm{C}$ (light hypothermia if it was $36-36.4{ }^{\mathrm{O}} \mathrm{C}$, medium hypothermia if $32-35.9^{\mathrm{O}} \mathrm{C}$, and heavy hypothermia if $\left.<32^{\mathrm{O}} \mathrm{C}\right) .^{1-3,6,7}$ The room temperature considered too low and therefore capable of causing hypothermia in baby was $<26^{\circ} \mathrm{C} .{ }^{1,2,10}$ The gestational age was calculated based on the Finstrom score (physical evaluation on hair, ear lobe, nipple, abdominal vein, hand nail, and plantar crease); the baby was considered premature if the gestational age was $<37$ weeks. When the birth weight is $<2500$ gram, it was considered as low birth weight. The baby was considered asphyxia if the APGAR score (appearance, pulse, grimace, activity, and respiration) during the first 15 minutes after birth $<7$. The measurement (of body and room temperatures) at the 0 minute is the measurement conducted from the 0 to the $5^{\text {th }}$ minute after birth (and before bath in the group immediately 
bathed after birth), the measurement at the $15^{\text {th }}$ minute was done 15 minutes after birth (and after birth in the group immediately bathed after birth), while the measurement at the $30^{\text {th }}$ minute was done 30 minutes after birth. The baby was considered to have a risk of infection if the Bergowitz score was $>3$.

The $\mathrm{X}^{2}$ test and the $t$ test were used to compare the characteristics of both groups in this study which was assumed to have a normal data distribution. The comparison of the occurences of hypothermia between the two groups of babies, namely the group immediately bathed after birth and the group not immediately bathed after birth, was analysed using $\mathrm{X}^{2}$ test, whereas in comparison of the mean body temperature between the two groups, the $t$ test was used. The Wilcoxon signed rank test was used for analyzing the change of body temperature in the three moments of measurement. The data was processed using Statistical Product and Service Solutions 9.0 for Windows, and the level of significancy adopted was $p<0.05$.

\section{RESULT}

Fourteen babies were excluded, including: two babies with too low room temperature, six babies which were born premature and with low birth weight, five babies born under asphyxia conditions, and one baby with anenchephaly. Both groups (the immediately and not immediately bathed after birth) did not show any different characteristics in terms of birth weight, gestational age, room temperature a moment after birth, sex, mode of delivery, as well as in terms of infection risk upon the babies (Table 1). There are seven babies that were not delivered spontaneously in the group immediately bathed (namely two babies through cesarean section and five through forceps extraction); in the group not immediately bathed there were 11 babies not delivered spontaneously (namely eight babies through cesarean section, two through forcep extraction, and one through vacuum extraction).

There was no significant difference in the mean body temperature between the two groups during the first minutes after birth (measurement at the 0 minute) and at 30 minutes after birth (Table 2). The measurement at 15 minutes, on the other hand, revealed that the mean body temperature of the immediately bathed group was significantly lower than that of the group not immediately bathed after birth.

The measurement at 0 to $15^{\text {th }}$ minute showed a decrease of $0.15^{\circ} \mathrm{C}$ in the mean of body temperature of the group of babies immediately bathed, which then increased by $0.12^{\circ} \mathrm{C}$ so that it eventually reached a level almost the same as the body temperature of the groups of babies not immediately bathed (Figure 1).

Table 1. Characteristics of the two groups $(\mathrm{N}=125)$ after exclusion

\begin{tabular}{|c|c|c|c|c|}
\hline Characteristics & $\begin{array}{c}\text { Immediately } \\
\text { bathed } \\
(\mathrm{N}=59)\end{array}$ & $\begin{array}{l}\text { Not immediately } \\
\text { bathed } \\
(\mathrm{N}=66)\end{array}$ & $\begin{array}{c}95 \% \\
\text { convidence } \\
\text { interval }\end{array}$ & $p$ \\
\hline Birth weight, g, mean (SD) & $3139.8(315.4)$ & $3228.0(360.5)$ & $-208.8 ; 32.4$ & 0.150 \\
\hline Gestational age, week, mean (SD) & $39.4(1.0)$ & $39.6(0.9)$ & $-0.6 ; 0.1$ & 0.243 \\
\hline \multicolumn{5}{|l|}{ Room temperature, ${ }^{\mathrm{O}} \mathrm{C}$, mean (SD) } \\
\hline The 0 minute* & $27.7(1.1)$ & $27.9(1.4)$ & $-0.7 ; 0.2$ & 0.343 \\
\hline The $15^{\text {th }}$ minute & $27.7(1.0)$ & $27.6(1.1)$ & $-0.2 ; 0.5$ & 0.462 \\
\hline The $30^{\text {th }}$ minute & $27.8(1.0)$ & $27.6(1.1)$ & $-0.2 ; 0.6$ & 0.260 \\
\hline \multicolumn{5}{|l|}{ Gender, total } \\
\hline Male & 32 & 38 & & 0.707 \\
\hline Female & 27 & 28 & & \\
\hline \multicolumn{5}{|l|}{ Mode of delivery, total } \\
\hline Spontaneous & 52 & 55 & & 0.445 \\
\hline Not spontaneous & 7 & 11 & & \\
\hline \multicolumn{5}{|l|}{ Risk of infection, total } \\
\hline With & 17 & 19 & & 0.997 \\
\hline Without & 42 & 47 & & \\
\hline
\end{tabular}

* measured at the first 5 minutes after birth 
The decrease in the mean body temperature of the groups immediately bathed was found to be statistically significant (Table 3). However, there was a significant increase in the mean body temperature of the group not immediately bathed, namely an increase by $0.09^{\circ} \mathrm{C}$ from the measurement at the 0 minute till at the $15^{\text {th }}$ minute. From the measurement at the $15^{\text {th }}$ minute till that at the $30^{\text {th }}$ minute there ocurred a decrease of the mean body temperature, but the decrease was only slight $\left(0.03^{\mathrm{O}} \mathrm{C}\right)$ and not statistically significant (Table 3).

Table 2. Mean body temperature of both groups at the $0,15^{\text {th }}$, and $30^{\text {th }}$ minute after birth

\begin{tabular}{|c|c|c|c|c|c|}
\hline \multirow{2}{*}{ Time of measurement* } & \multicolumn{2}{|c|}{ Body temperature, ${ }^{\circ} \mathrm{C}$, mean (SD) } & \multirow{2}{*}{$\begin{array}{c}95 \% \\
\text { convidence } \\
\text { interval }\end{array}$} & \multirow{2}{*}{$\mathrm{t}$} & \multirow{2}{*}{$p$} \\
\hline & $\begin{array}{c}\text { Immediately } \\
\text { bathed } \dagger \\
(\mathrm{N}=59)\end{array}$ & $\begin{array}{c}\text { Not immediately } \\
\text { bathed }+ \\
(\mathrm{N}=59)\end{array}$ & & & \\
\hline The 0 minute & $36.99(0.24)$ & $36.93(0.25)$ & $-0.02 ; 0.15$ & 1.503 & 0.135 \\
\hline The $15^{\text {th }}$ minute & $36.84(0.25)$ & $37.02(0.27)$ & $-0.2 ;-0.08$ & -3.868 & 0.0001 \\
\hline The $30^{\text {th }}$ minute & $36.96(0.25)$ & $36.99(0.23)$ & $-0.12 ; 0.05$ & -0.755 & 0.451 \\
\hline
\end{tabular}

* measured at the first 5 minutes, the $15^{\text {th }}$ minute, and the $30^{\text {th }}$ after birth

$\dagger$ bathed at the $10^{\text {th }}$ minute after birth

\pm bathed at the $2^{\text {nd }}-6^{\text {th }}$ hour after birth

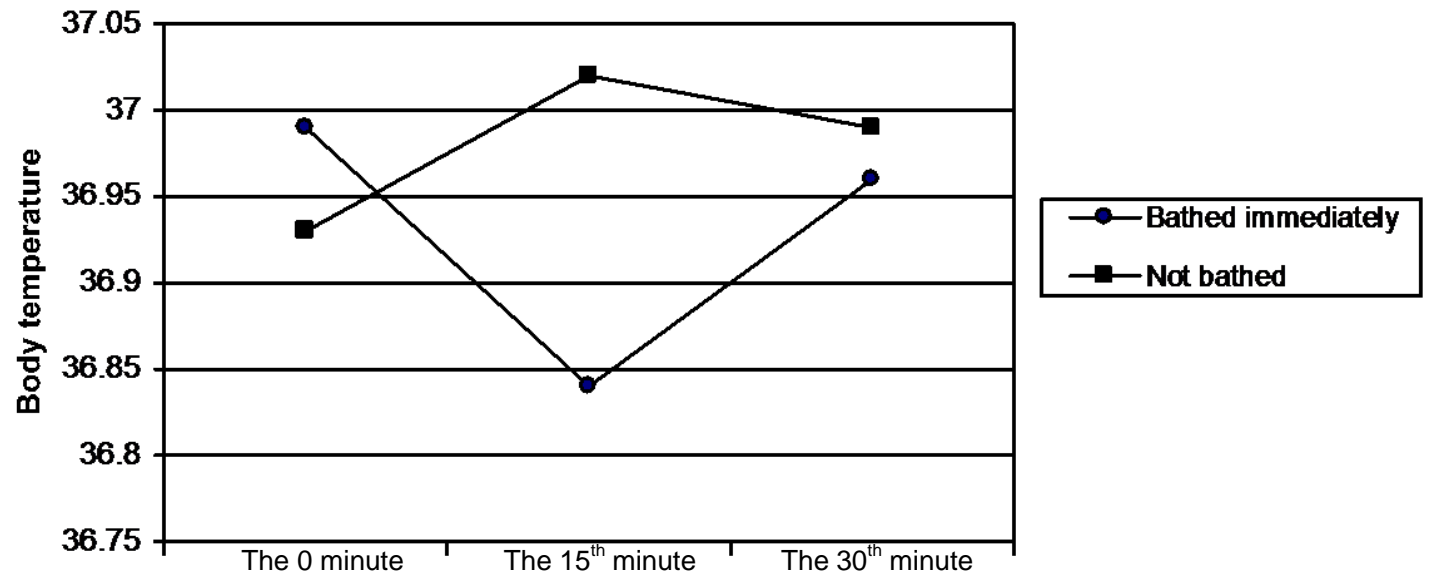

Time of measurement

Figure 1. Graphic of the changes in mean body temperature of both groups at the $0,15^{\text {th }}$, and $30^{\text {th }}$ minute after birth

Table 3. Changes in mean boy temperature of both groups at the $0,15^{\text {th }}$, and $30^{\text {th }}$ minute after birth

\begin{tabular}{|c|c|c|c|c|c|}
\hline & \multicolumn{3}{|c|}{ Body temperature, ${ }^{\mathrm{O}} \mathrm{C}$, mean $(\mathrm{SD}) *$} & \multirow{2}{*}{$\mathrm{Z}$} & \multirow{2}{*}{$p$} \\
\hline & The 0 minute & The $15^{\text {th }}$ minute & The $30^{\text {th }}$ minute & & \\
\hline $\begin{array}{l}\text { Immediately bathed } \dagger \\
(\mathrm{N}=59)\end{array}$ & $36.99(0.24)$ & $\begin{array}{l}36.84(0.25) \\
36.84(0.25)\end{array}$ & $36.96(0.25)$ & $\begin{array}{l}-4.006 \\
-2.864\end{array}$ & $\begin{array}{c}0.0001 \\
0.004\end{array}$ \\
\hline $\begin{array}{l}\text { Not immediately bathed } \$ \\
(\mathrm{~N}=66)\end{array}$ & $36.93(0.25)$ & $\begin{array}{l}37.02(0.27) \\
37.02(0.27)\end{array}$ & $36.99(0.23)$ & $\begin{array}{l}-3.668 \\
-0.766\end{array}$ & $\begin{array}{c}0.0001 \\
0.444\end{array}$ \\
\hline
\end{tabular}

* measured at the first 5 minutes, the $15^{\text {th }}$ minute, and the $30^{\text {th }}$ after birth

$\dagger$ bathed at the $10^{\text {th }}$ minute after birth

t bathed at the $2^{\text {nd }}-6^{\text {th }}$ hour after birth 
No cases of hypothermia were found in the two groups during the measurement at the 0 minute after birth, and neither were they during the measurement at the $30^{\text {th }}$ minute. Cases of hypothermia did occur in the groups during measurement at the $15^{\text {th }}$ minute after birth, namely cases such as the following: four (6.8\%) cases of hypothermia (in which three babies were with the body temperature of $36.4^{\circ} \mathrm{C}$ and one with $36.3{ }^{\circ} \mathrm{C}$ ) occurred among the 59 babies immediately bathed after delivery; and one (1.5\%) case of hypothermia (with body temperature of 36.4 ${ }^{\circ} \mathrm{C}$ ) among the 66 babies not immediately bathed after delivery (Table 4). Statistically, there was no significant difference in the number of hypothermia cases between the two groups.

Table 4. Occurrence of hypothermia in both groups at te $15^{\text {th }}$ minute after birth

\begin{tabular}{lccc}
\hline & $\begin{array}{c}\text { Hypothermia, } \\
\text { number }(\%)^{*}\end{array}$ & $\begin{array}{c}\text { Normothermia, } \\
\text { number }(\%)^{* *}\end{array}$ & Total \\
\hline $\begin{array}{l}\text { Immediately } \\
\text { bathed } \dagger\end{array}$ & $4(6,8)$ & $55(93,2)$ & 59 \\
$\begin{array}{l}\text { Not immediately } \\
\text { bathed } \dagger\end{array}$ & $1(1,5)$ & $65(98,5)$ & 66 \\
\hline Total & 5 & 120 & 125 \\
\hline $\begin{array}{l}\mathrm{X}^{2}=2.248 \quad \mathrm{df}=1 \quad p=0.134 \text { (with Yate's correction) } \\
* \text { body temperature under } 36.5^{\circ} \mathrm{C}\end{array}$ \\
$* *$ body temperature between $36.5-37.5^{\circ} \mathrm{C}$ \\
$\begin{array}{l}\dagger \text { bathed at the } 10^{\text {th }} \text { minute after birth } \\
+ \text { bathed at the } 2^{\text {nd }}-6^{\text {th }} \text { hour after birth }\end{array}$
\end{tabular}

\section{DISCUSSION}

Through the non random sampling in this study, it could be that the trial and control groups become different, however it has been proven that the two study groups had the same characteristics as shown in Table 1 . The role of other factors of hypothermia risk have been accounted for excluding those babies with the factor of hypothermia risk, which include: asphyxia, prematurity or low birth weight, too low room temperature $\left(<26^{\circ} \mathrm{C}\right)$, and serious congenital abnormality. Based on this, we believe that in this study that bathing was the only influence in the change in body temperature of the baby during the first few minutes after birth.

Another risk factor which contributes to the occurrence of hypothermia in the newborn baby is the anesthetic drugs given to the mother, ${ }^{1,5,10}$ which is frequently done in the cesarean section. This can suppress the baby's thermoregulation center, but it depends on the kid, dosage, and duration of the anesthetic drug given., ${ }^{5,6,10}$ It is not only the thermoregulation center of the brain stem which become suppressed, but the respiration and vasomotor centers are equally suppressed, and can cause asphyxia. ${ }^{5}$ In the sample of this study, there were 10 babies born by cesarean section, but no data was available about the kind, dosage, and duration of anasthetics used. We thought that if the injection of anesthetic suppresses the thermoregulation center of the baby, then asphyxia will also occur during delivery. We excluded the cases of asphyxia in our study, so we excluded the babies with risk factor of the anesthetic to the mothers affecting the body temperature from the study groups.

Bathing the baby immediately after birth (in the first ten minutes after birth) in our study caused a significant decrease of $0.15^{\circ} \mathrm{C}$ in the body temperature. Takayama et al found the same thing in the group of babies immediately bathed after birth, namely the decrease of body temperature of $0.20^{\circ} \mathrm{C} .{ }^{11}$ Using warm bathing water $\left(30^{\circ} \mathrm{C}\right)$ does not guarantee maintaining the baby's body temperature. Once the baby is taken out from the bath tub, the baby begins to get cold because of evaporation of the remaining bathing water on the skin of the baby. ${ }^{1-4,6,7}$ If the drying with a dry towel is not immediately done, it is quite likely that the body temperature will decrease. The thermoregulation system is not functioning maximally during the first few hours of the baby's birth and is unable to compensate. The decrease of the body temperature in this study might also be caused by the process of conduction because the baby's body is not dried with a towel below the radiant warmer, which causes the transfer of heat from the baby's body to its bed. ${ }^{4}$ There is little possibility in this study for the process of heat loss through radiation due to room temperature; this is due to exclusion of babies whose room temperature was too cold $\left(<26^{\circ} \mathrm{C}\right)$. There is also very little possibility for eat loss through convection, because we ensured that no significant air flow occurred in the baby's room. Loss of body heat through radiation process can also occur if the glass of the window is colder than the air in the room of the baby; however, this seems impossible in the tropical location of this study. It is different from a study done in Nepal, where the mean room temperature $<25{ }^{\circ} \mathrm{C}$ caused the occurrence of long-lasting hypothermia in the newborn babies (the mean body temperature reaches only $36^{\circ} \mathrm{C}$ at 6.4 hours after delivery). ${ }^{12}$ In the 
study conducted by Nako et al no difference in mean body temperature between the baby immediately bathed and those not immediately bathed after birth was found. ${ }^{13}$ Unfortunately the measurement of the body temperature in Nako's study was conducted 20 minutes after the babies were bathed so that it was not known what the body temperature precisely was after the baby was bathed. Similar to the result reported by Nako et al, Penny did not find a decrease in the mean of the baby's body temperature immediately bathed after birth. ${ }^{14}$ The decrease of body temperature in the groups under our study did not occur when the baby was being bathed because the temperature of $39^{\circ} \mathrm{C}$ of the bathing water and the fact that the bathing of the baby was done within a short time, namely about 1 minute only. It is indeed the action taken after the bathing which can decrease of the body temperature such as the slow drying of the baby, as well as not wrapping the baby with a blanket. It is likely that those things do not happen in the babies under Penny's study because of the high skill of the health staff supported by good medical facilities.

It is difficult to change the tradition of bathing the baby immediately after birth, especially in the peripheral areas out of health center. The baby not immediately bathed after birth looks dirty and smells unpleasant from the remaining vernix, amniotic fluid, and blood. However, it need to be remembered that the benefit of bathing the babies immediately after birth is less compared to its harm. Moreover, delaying the bathing of the baby does not risk infection; according to the report made by Henningsson et al, there was no difference in terms of skin infection and colonisation of bacteria in the umbilicals between the groups of babies bathed and the group of babies only scrubbed after delivery. ${ }^{15}$

Cheah et al said that hypothermia before the babies were bathed occurred when the babies were not laid down under radiant warmer before the bath and the temperature of the delivery room was low. ${ }^{10} \mathrm{We}$ did not find any case of hypothermia when doing the measurement at the 0 minute or before the babies of the two groups were bathed, so the low temperature of the delivery and baby's room were not a risk factor in both groups under study. The risk factor related to hypothermia after the bathing in Cheah's study, on the other hand, was the low temperature of the baby's room, the low body temperature before bathing, and the length of time spent during the bath. ${ }^{10}$ The method of measurement conducted by Cheah et al was based on aural temperature, which is considered less accurate in reflecting the actual temperature of the body of the newborn baby, ${ }^{8,9}$ perhaps due to the difficulty in installing the temperature censoring device correctly in the ear of newborn babies. ${ }^{9}$

While the occurrence of hypothermia in the two groups of babies was statistically not significant, clinically it was very important. The occurrence of hypothermia in our study was found more often in the babies bathed immediately, although these hypothermia were in the light category (in which the body temperature is between $36-36,4^{\circ} \mathrm{C}$ ). The temperature of these babies became normal again during the measurement at the $30^{\text {th }}$ minute after birth. However if these light hypothermia occur in less healthy babies, it may grow into intermediate or even severe hypothermia which threatens life.

Full-term babies who are healthy will have the optimum thermoregulative capability after the first two hours of birth. ${ }^{16,17}$ After that time the baby produce body heat by increasing body metabolism; this is especially possible after the baby gets food intake. The decrease of baby's body temperature bathed immediately at the $15^{\text {th }}$ minute in our study returned to a level almost the same as the baby's body temperature not bathed immediately at the $30^{\text {th }}$ minute. The increase is perhaps caused by the increase in the consumption of oxygen, the shivering response of the skeletal muscles, thermogenesis of the brown fat tissue, and by the cycling of ion in certain tissues, but not by the increase in the rate of body metabolism. ${ }^{18,19}$ Wrapping the baby with a blanket and laying it under radiant warmer can perhaps help to prevent the loss of body temperature which has just been produced. ${ }^{20,21}$ Grover et al found an increase in the rectal temperature of $0.06{ }^{\circ} \mathrm{C}$ per hour, and the middle of lower leg skin temperature as much as $2.67^{\circ} \mathrm{C}$ per hour after the baby's body was wrapped in a blanket and its head covered with a cap. ${ }^{22}$

There are other opinions that bathing the baby can be done one hour after birth. As mentioned by Varda et $a l$, there was no difference in the body temperature in the babies bathed at one hour and two hours after birth. ${ }^{23}$ Therefore, Varda et al stated that healthy fullterm babies with axillary temperature $\geq 36.8^{\circ} \mathrm{C}$ can be bathed at one hour after birth, and not necessarily need to wait for two hours of age. It is thought that by this time the body temperature is fairly stable and can compensate cold stress. ${ }^{21,23,24}$ One concern of the study by Varda et al was that the temperature measurement of the axilla is not very accurate for 
describing the exact body temperature of the newborn baby because it is still influenced by the brown fat tissue found in abundance in the axillary area. ${ }^{8}$ Therefore, despite a decrease in the rectal temperature,the temperature in the axilla can still be normal.

Unlike the babies immediately bathed after birth, at the $15^{\text {th }}$ minute there was an increase in baby's body temperature not immediately bathed in comparison to the measurement at birth. Since these babies are laid down under radiant warmer and wrapped in the blanket, eventually their body temperature is not lost, and may eventually reach the optimum level. This indicates the improvement in the thermoregulative system in the baby's body after birth. Although, there was a slight decrease in the baby's body temperature bathed not immediately at the $30^{\text {th }}$ minute in comparison was relatively constant from the $15^{\text {th }}$ minute to the $30^{\text {th }}$ minute after delivery.

Based on this study result, it can be said that the bathing of the baby immediately after birth can lead to a decrease of the body temperature of the baby, which sometimes leads to hypothermia. The quality of the health staff and medical facilities have great role in preventing the occurrence of hypothermia. This study was conucted at the hospital with good facilities for preventing hypothermia in newborn babies so there may be a greater problem in other areas with poorer facilities. Nevertheless, this study shows that a decrease of body temperature can also occur in the centers with good medical facilities if the baby is bathed too early after birth.

In this study we only differentiate the body temperature between the babies immediately bathed and not immediately bathd at the same first minute after birth. It would be interesting to study what happens to the baby's body temperature bathed two hours or more after birth when the thermoregulation system of the baby's body is already optimum and its body temperature is relatively stable.

\section{CONCLUSION}

Bathing healthy full-term baby immediately after birth can cause a decrease in the baby's body temperature, however this decrease did not significantly increase the occurrence of hypothermia. Despite the sufficient availability of medical facilities for treating newborn babies, it is no longer recommended that babies be immediately bathed after birth.

\section{REFERENCES}

1. Maternal Health and Safe Motherhood Programme Division of Family Health, World Health Organization. Thermal Control of the Newborn. Geneva, 1996.p.1-37.

2. Departemen Kesehatan RI. Bayi Baru Lahir. $3^{\text {rd }}$ edition. Jakarta, 1996. p.1-39.

3. Blake WW, Murray JA. Heat Balance. In: Merenstein GB, Garder SL, editors. Handbook of Neonatal Intensive Care. $3^{\text {rd }}$ edition. St. Louis: Mosby Year Book Inc, 1993. p.10014.

4. Leblanc MH. Neonatal Heat Transfer. In: Polin RA, Fox WW, editors. Fetal and Neonatal Physiology. Philadelphia: WB Saunders Company, 1997.p.483-7.

5. Corneli HM. Accidental hypothermia. J Pediatr 1992;120:671-9.

6. Scopes JW. Thermoregulation in the Newborn. In: Avery GB, editor. Neonatology - Patophysiology and Management of The Newborn. $2^{\text {nd }}$ edition. Philadelphia: B Lippincott Company, 1981.p.171-80.

7. Margit, Glatzl A, Hawlik, Bell EF. Environmental Temperature Control. In: Polin RA, Fox WW, editors. Fetal and Neonatal Physiology. Philadelphia: WB Saunders Company, 1997.p.515-24.

8. Yetman RJ, Coody DK, West MS, Montgomery D, Brown D. Comparison of Temperature Measurements by an Aural Infrared Thermometer with Measurements by Traditional Rectal and Axillary Techniques. J Pediatr 1993;122:769-73.

9. Smith AP, Barber N, Coody DK, West MW, Yetman RJ. Comparison of Aural Infrared with Traditional Rectal Temperatures in Children from Birth to Age Three Years. J Pediatr 1994;125:83-5.

10. Cheach FC, Boo NY. Risk factors associated with neonatal hypothermia during cleaning of newborn infants in labour rooms. J Trop Pediatr 2000;46:46-50.

11. Takayama Jl, Teng W, Uyemoto J, Newman TB, Pantell $\mathrm{RH}$. Body temperature of newborns: what is normal? Clin Pediatr 2000;39:503-10.

12. Ellis M, Manandhar N, Shakya U, Manandhar DS, Fawdry A, Costello AM. Postnatal hypothermia and cold stress among newborn infants in Nepal monitored by continuous ambulatory recording. Arch Dis Child 1996;75:F42-5.

13. Nako Y, Harigaya A, Tomomasa T, Morikawa A, Amada M, Kijima C, Tsukagoshi S. Effects of bathing immediately after birth on early neonatal adaptation and morbidity: a prospective randomised comparative study. Pediatr Int 2000;42:517-22.

14. Penny-MacGillivray T. A newborn's first bath: when? J Obstet Gynecol Neonatal Nurs 1996;25:481-7.

15. Henningsson A, Nystrom B, Tunnel R. Bathing or wasing babies after birth? Lancet 1981;26:1401-3.

16. Cloherty JP. Temperature Control. In: Cloherty JP, Stark AR, editors. Manual of Neonatal Care. Edisi ke-1. Boston: Little Brown Company, 1980.p.349-53. 
17. Sinclair JC. Management of The Thermal Environment. In: Sinclair JC, Bracken MB, editors. Effective Care of The Newborn Infant. Oxford: Oxford University Press, 1992.p.40-54.

18. Bruck K. Neonatal Thermal Regulation. In: Polin RA, Fox WW, editors. Fetal and Neonatal Physiology. Philadelphia: WB Saunders Company, 1997.p.488-513.

19. Power GG. Fetal Thermoregulation. In: Polin RA, Fox WW, editors. Fetal and Neonatal Physiology. Philadelphia: WB Saunders Company, 1997.p.477-82.

20. Cottrell BH, Todd NA. Home care concern for the normal newborn. Home Care Provid 1988;3:2937.
21. Peters KL. Bathing premature infants: physiological and behavioural consequences. Am J Crit Care 1998;7:90-100.

22. Grover G, Berkowitz CD, Lewis RJ, Thompson M, Berry L, Seidel J. The Effects of Bundling on Infant Temperature. Pediatrics 1994;94:669-73.

23. Varda KE, Behnke RS. The effect of timing of initial bath on newborn's temperature. J Obstet Gynecol Neonatal Nurs 2000;29:27-32.

24. Thompson AE. Environmental Emergencies. Dalam: Fleisher GR, Ludwig S, Silverman BK, editors. Synopsis of Pediatric Emergency Medicine. Baltimore: William \& Wilkins, 1996.p.447-62. 
